\title{
"Interaction Pattern of Economics Teachers in Cross River State Secondary Schools, Nigeria"
}

\author{
${ }^{1}$ Emmanuel N. Odu, ${ }^{2}$ Francisca Odigwe, ${ }^{3}$ Charles D. Ekpenyong \\ ${ }^{I}$ Affiliation: Institute of Policy and Public Administration, University of Calabar, Calabar, Nigeria. \\ ${ }^{2}$ Department: Department of Educational Administration and Planning, University of Calabar, Calabar, \\ Nigeria. \\ ${ }^{3}$ Affiliation: Department of Economics, University of Calabar, Calabar, Nigeria.
}

\begin{abstract}
The study focused on Interaction Pattern of Economics Teachers in Cross River State Secondary Schools. A sample size of 400 (consisting 350 students and 50 teachers) was used for the study. Stratified random sampling was adopted as a sampling technique. Two hypotheses were tested in the study using Onesample T-test. It was found that: Students of Economics in Cross River State secondary schools do not consider the interactive pattern of their teachers as adequate and helping them better achieve academically, and that students of Economics in Cross River State secondary schools do not consider the student-student interactive pattern as adequate and helping them better achieve academically. Recommendations were made based on the findings of the study.
\end{abstract}

\section{Introduction}

The dynamics of teaching is a crucial factor in how much students learn (Grouws, 1981). Thoughstudents' performance may not be a simple direct consequence of the teachers' teaching act, the latterhas a lot to do with classroom learning. According to Kalu (2010), teachers establish the pattern of general conduct during alesson, while on their part students establish certain types of behaviour to coincide with this pattern.Consequently the students participate to varying degrees in different classes and react differently todifferent teachers. This combined instructional pattern and student participation lead to a specific classroom environment characterized by specific interaction patterns. The instructional theory of 'social emotional climate' hypothesizes that this environment has a direct effect on both studentattitudes and achievement (Hager, 1974).

In Nigeria, the few interaction studies (e.g. Ajayelami, 1983; Akuezuilo, 1987; Domike, 2002; Emah,1998; Iyewarum, 1983; Mani, 1986; Okafor, 1993; Okebukela, 1985; Okebukola\&Ogunniyi, 1984;Ogunkola, 1999; Udeani, 1992) have indicated that some relationship exists between classroom interaction pattern and students' achievement. Okebukola(1986) reports that classroom participationhad the greatest independent contribution (22\%) to the variance in achievement scores while Udeani(1992) reports that classroom interaction accounted for about $74 \%$ and $71 \%$ of the variation in studentscognitive achievement and process skill acquisition respectively. Also Okafor (1993) found a positive relationship between classroom interaction behaviour and students' level of achievement.

Teacher effectiveness is simply the ability of the teaching activities of the teacher to produce the expected good learning outcomes on the learner. Bad or negative effects are excluded in teacher effectiveness research. Therefore, teacher effectiveness is the production of expected good learning outcomes (cognitive, affective and psychomotor) by the good teaching behaviours of the teacher which encouraged maximum good learning behaviours from the students (Brophy and Good, 1956). These definitions highlight the conceptual complexity of teacher effectiveness that led to the difficulty in its measurement. Hence Medley (1987) demanded that three distinct criteria must be used to assess teacher effectiveness, as follows: (a) behaviours of the teacher while teaching (b) learning behaviours or experiences of students which the teaching provided and (c) the outcomes of the teaching (students achievement). These, criteria therefore agreed with Brophy and Good (1986) who had earlier stated that it is a misnomer to equate teacher effectiveness with only success in producing students achievement gain.

Classroom interaction analysis is the process of studying classroom interaction patterns by examining the various elements of the instructional system and their reciprocal inter-play or relationships. The aim being to understand, describe and assess the way in which the teaching-learning process happens or moves progressively. Galton (1995) defined interaction analysis as a structured or systematic classroom observational technique derived from Flanders Interaction Analysis Category System (FIAC).

\section{Statement of the Problem}

The need for secondary school students in Cross River and Nigeria at large to reach their full academic and intellectual potentials presents a problem which this study intends to contribute knowledge to finding its 
solution. It is generally known that performance in SSCE has been deplorable over the years, this is so generally and in Economics as a subject. The need to transform the secondary sub-sector of the education sector of Nigeria necessitates the deployment of every necessary strategy to get the students improve the academic attainment levels, which in turn will reflect in their performance at external examinations e.g. SSCE.Besides, according to Ogbu (2011), teachers in the field were not effective in the discharge of their duty because emphasis were laid only on paper qualification. These teachers are not truly interactive in their classes and also lack the knowledge and application of classroom interaction patterns and analysis. The teaching or leadership styles of teachers has to be considered in the objective of finding solution to poor learning outcomes in the secondary school sector in Cross River State. This informed the need to study the interaction pattern of Economics teachers in Cross River State secondary schools with the view to helping students improve their academic and intellectual outcomes.

\section{Objective}

Specifically, the objectives of this study include:

To investigate teacher-student interaction pattern in Economics subject in secondary schools in Cross River State, Nigeria.

To investigate student-student interaction pattern in Economics subject in secondary schools in Cross River State, Nigeria.

\section{Research Questions}

To what extent do students of Economics in Cross River State secondary schools consider the interactive pattern of their teachers as adequate and helping them better achieve academically?

To what extent do students of Economics in Cross River State secondary schools consider their student-student interaction pattern as adequate and helping them better achieve academically?

\section{Hypotheses}

The following hypotheses which form the focus of this study are hereby stated in null form:

- Students of Economics in Cross River State secondary schools do not consider the interactive pattern of their teachers as adequate and helping them better achieve academically.

- Students of Economics in Cross River State secondary schools do not consider the student-student interactive pattern as adequate and helping them better achieve academically

\section{Research Methodology}

\section{Study Area}

The study area for this research is Calabar Metropolis (consisting of Calabar Municipality and Calabar South Local Governments). Calabar is the capital of Cross River State in the south-south geopolitical zone of Nigeria.

\section{Sample size}

Sample size of 400 (consisting of 350 students and 50 teachers of Economics) is used for the purpose of this study. 200 respondents were interviewed in each of the 2 (Calabar Municipality and Calabar South). This is for the purpose of achieving a representative sample for the population.

\section{Sampling technique}

Stratified random sampling was used for the purpose of this study. Stratification was done based on whether the students offered Economics as a subject or not. Then, Simple Random Sampling was done to give every person equal chances of being selected for the survey, this is for the purpose of reducing 'bias' to the barest minimum, and getting a sample that is a fair representation of the population.

\section{Data Collection Procedure}

Data collection was done by the administration of questionnaire to every respondent interviewed for the purpose of the study. 400 questionnaires were administered and retrieved for the purpose of the study.

\section{Analytical Procedure}

One-sample T-test is used for the purpose of this study. One-sample T-test is used because it is conventionally accepted as a tool for making deductive inference based on observation of data. 


\section{Results}

\section{Results and Discussion}

Likert scale ranking is used for the purpose of testing observation on the two variable (TeacherTeacher, and Student-Student) as follows:

4-Strongly Agree; 3-Agree; 2-Disagree; 1-Strongly Disagree.

From Table 1 below, it is shown that from the observation of 400 respondents, Mean $=1.76$. This indicates that most of the respondents tend towards 'Disagree' with the notion that Teacher-Student interaction pattern helps them achieve better academically.

From the Table 2 below, it is shown that from the observation of 400 respondents, Mean $=1.75$. This indicates that most of the respondents tend towards'Disagree' with the notion that Student-Student interaction pattern help them achieve better academically.

Table 1: Descriptive Statistics for Observation of Teacher-Teacher Interaction Pattern

Source: Field Survey, 2013.

\begin{tabular}{|l|l|}
\hline & TEACHER_STUDENT \\
\hline No. of Cases & 400 \\
\hline Minimum & 1.000 \\
\hline Maximum & 4.000 \\
\hline Arithmetic Mean & 1.760 \\
\hline Standard Deviation & 0.737 \\
\hline
\end{tabular}

Table 2: Descriptive Statistics for Observation on Student-Student Interaction Pattern

\begin{tabular}{|l|l|}
\hline & STUDENT_STUDENT \\
\hline No. of Cases & 400 \\
\hline Minimum & 1.000 \\
\hline Maximum & 3.000 \\
\hline Arithmetic Mean & 1.750 \\
\hline Standard Deviation & 0.674 \\
\hline
\end{tabular}

Source: Field Survey, 2013.

\section{Test of Hypotheses}

Table 3: Test of Hypotheses

H0: Mean $=2.00$ vs. H1: Mean > 2.00

Table 3 shows the result on One-sample T-test carried out on each of the variables Teacher-Student interaction pattern, and Student-Student interaction pattern.

\begin{tabular}{|l|l|l|l|l|l|l|l|}
\hline Variable & $\mathrm{N}$ & $\begin{array}{l}\text { Mean } \\
\text { Standard } \\
\text { Deviation }\end{array}$ & $\begin{array}{l}95.00 \% \\
\text { Confidence } \\
\text { Bound }\end{array}$ & $\mathrm{t}$ & $\mathrm{df}$ & $\mathrm{p}$-Value \\
\hline TEACHER_STUDENT & 400.000 & 1.760 & 0.737 & 1.699 & -6.409 & 399.000 & 1.000 \\
\hline STUDENT_STUDENT & 400.000 & 1.750 & 0.674 & 1.694 & -7.224 & 399.000 & 1.000 \\
\hline
\end{tabular}

Hypothesis One

Test Statistic $\mathrm{T}=\mathrm{X}-\mu /(\mathrm{s} / \sqrt{ } \mathrm{n})$

$$
\begin{aligned}
& \text { Where } \mathrm{X}=\text { observed mean } \\
& \mu=\text { population mean } \\
& \mathrm{S}=\text { standard deviation } \\
& \mathrm{n}=\text { number of observations } \\
& =1.76-2 /(0.737 / 20) \\
& =-0.24 / 0.0369 \\
& =-6.504
\end{aligned}
$$

Since Test Statistic T (-6.504) is less than tabulated statistic t (-6.409), we do not have sufficient statistical evidence to reject $\mathrm{H}_{0}$, we therefore accept $\mathrm{H}_{0}$ and conclude that: Students of Economics in Cross River 
State secondary schools do not consider the interactive pattern of their teachers as adequate and helping them better achieve academically.

Hypothesis

Test Statistic $\mathrm{T}=\mathrm{X}-\mu /(\mathrm{s} / \sqrt{ } \mathrm{n})$

Where $\mathrm{X}=$ observed mean

$\mu=$ population mean

$\mathrm{s}=$ standard deviation

$\mathrm{n}=$ number of observations

$=1.75-2 /(0.674 / 20)$

$=-0.25 / 0.0337$

$=-7.418$

Since Test Statistic T (-7.418) is less than tabulated statistic t (-7.224), we do not have sufficient statistical evidence to reject $\mathrm{H}_{0}$, we therefore accept $\mathrm{H}_{0}$ and conclude that: Students of Economics in Cross River State secondary schools do not consider the student-student interactive pattern as adequate and helping them better achieve academically

\section{Discussion}

The results from the tests of the two hypotheses suggest a critical condition of secondary school education in the study area (Calabar Metropolis of Cross River State), especially in the area of teacher performance. The findings of this study indicate that students of Economics in secondary schools do not consider the interaction pattern of Economics teachers as adequate and helping them achieve better academically. The findings also show that students of Economics in secondary schools do not consider their interaction with fellow students as adequate and helping them better achieve academically. This may be the reason for poor performance in Economics and perhaps other subjects in external exams such as WAEC/SSCE in Cross River as a state (Aina, 2006).

The findings of this study is supported by McDonald (1976), he reported that teaching performance accounted for a third to half of the variance in pupil spring scores when their fall scores were partialled out, and about half of the variance in mean-change scores in maths but only about $10 \%$ of the variance in reading. This view is further corroborated by the views and works of other scholars such as Ajayelami, 1983; Akuezuilo, 1987; Domike, 2002; Emah,1998; Iyewarum, 1983; Mani, 1986; Okafor, 1993; Okebukela, 1985; Okebukola\&Ogunniyi, 1984;Ogunkola, 1999; Udeani, 1992) have indicated that some relationship exists between classroominteraction pattern and students' achievement. Okebukola(1986) reports that classroom participation had the greatest independent contribution (22\%) to the variance in achievement scorewhileUdeani(1992) reports that classroom interaction accounted for about $74 \%$ and $71 \%$ of the variation in studentscognitive achievement and process skill acquisition respectively. Also Okafor (1993) found a positiverelationship between classroom interaction behaviour and students' level of achievement.Incidentally, these few studies on interaction patterns in Nigerian classrooms were mostly in Biologyclassrooms. Not much has been done in the subject-matter of physics.

The findings of this suggest that the leadership style of Economics teachers in and out of the class with regards to how they help the students achieve better academically needs to improved. These findings are in consonance with the findings of Ogbu (2010) who stated that these resulted to the noted problems of persistent students' poor cognitive achievement, loss of interest, poor attitude to lessons and programmes, students dropout, general apathy and even closure of some technical colleges or departments as evident in Cross River state (NABTEB, 2006 and Ama, 2006). Having noted the ineffective, non-integrative and inefficient teaching methods and techniques generally applied by technical teachers, Oyelami (2000) therefore attributed the above problems to teacher ineffectiveness.

\section{Conclusion}

From the findings of this study, it is shown that Economics teachers' interaction pattern with students of Economics does not bring out the best in the students of secondary schools in Calabar Metropolis. According to Ogbu (2010), now, the fact remains that not all holders of certificates or degrees in Nigeria can be effective in their job performance as teachers in secondary schools. Emphasis should be focusedonteachers interactive pattern with the students with the view to bringing out the best in the students of secondary schools.

\section{Recommendation}

In his study, Ogbu (2010) stated that theoretically, the assumption is that teacher effectiveness correlates positively or equates with the theoretical curriculum which the teacher graduated from. Therefore emphasis must be made in teacher training courses (both pre- and in-service) on the art of using interactive patterns to bring out the best in learners by the teacher. Ogbu (2010) further stated that one of the greatest 
problems facing Nigerian educational system is lack of an established and constantly used bench mark for assessing teachers' effectiveness practically on graduation, recruitment, promotion and day- to- day fitness for the job.This calls for an assessment benchmark to ensure that all-comers that are not practically effective in their job performance are shown their way out.

Apart from building a good teacher-student interaction pattern, teachers should be helped in the art of inspiring students to adopt student-student interaction patterns not just for social purposes, but for the objective of bringing out the best in them academically also. The relevance of education cannot be overemphasized, especially in Nigeria quest to attain the millennium development goals, in that case, all must be done to make the secondary sub-sector of the education successful.

This researcher also recommends that these strategies should not only by focused on Economics as a subject, but implemented for teachers across board in the secondary sector, and perhaps other sub-sectors e.g. primary and tertiary sub-sectors too.

\section{References}

[1] Aina O. (2006) Technical and Vocational Education (TVE) in Nigeria: The way Forward. Being a paper delivered at Kanno, Maiduguri, Port Hacourt, Aba, Owerri and Lafia on February 3, 7, 10, 14, 17, and 21 respectively in Education trust Fund Sensitization workshops on the importance of TVE organize by Education Trust Fund.

[2] Ajayelami, D.A 1983) A study of intellectual transactions in some Nigerian Chemistry classroomsand implications for Nigeria based classroom research. Lagos Educational Review, 3 (1),19- 24.

[3] Akuezuilo, E. O. (1987) Science teacher effectiveness and classroom behaviour.UnpublishedPh.DThesis,University of Jos, Nigeria.

[4] Brophy, J. and Good, T. L. (1986) Teacher behaviour and student achievement.In M.C. Wittrock (Ed).Handbook of research on teaching 3rd ed. a project of the American educational research association. New York. Simon and Schuster Macmillan 328-375.

[5] Domike, G. C (2002) Teacher - pupil interaction patterns and pupils' scienceachievement in ImoState. Unpublished PhD Thesis, University of Calabar, Nigeria.

[6] Emah, I. E (1998) Presage variables and verbal interaction patterns in Social studies classrooms inAkwaIbom State. Unpublished Ph.D Thesis, University of Calabar, Nigeria.

[7] Galton, M.(1995) classroom observation. In T. Husen and T.N Postlethwaite (Eds). The international encyclopedia of education.2nd Ed. vol. 2. Oxford: Pergamon 811-816.

[8] Grouws, D (1981) An approach to improving teacher effectiveness. Cambridge Journal of Education11 (1), 2 - 14.

[9] Hager, W. R (1974) An investigation of verbal behaviour and learning climate in undergraduateengineering classrooms. Journal of Research in Science Teaching, 11 (2), $121-131$.

[10] Iyewarum, S. A (1983) A study of the relationship between teachers' behaviour and students'achievement in science classes. Journal of the Science Teachers Association of Nigeria, 21(2), $45-49$.

[11] Kalu I. (2008). Classroom Interaction Patterns and Students` Learning Outcomes in Physics.MedwelJournals. Volume: 3, Issue: 1, Page No.: 57-60

[12] Mani, S. (1986). Process factors and mathematics teachers' effectiveness.Mathematique, 14 (3), 92 - 97.

[13] Medley, D.M.(1987) Criteria for evaluating teaching. In M. J. Dunkin (Ed).the international Encyclopedia of teaching and teacher Education. Oxford; Pergamon Press169-180.

[14] National Business and Technical Examination Board (2006).Summated national technical certificate examination result in electrical, radio and television works for south-eastern technical colleges 2000-2005. Benin city; Registrars office.

[15] Ogunkola, O. J. (1999) Interaction patterns in primary school Science Classrooms in Ijebu - Ode,Ogun State, Nigeria. African Journal of Educational Research, 5 (1), $51-61$.

[16] Okafor, L. C. (1993) Analysis of Classroom interaction patterns in Biology in Secondary Schools inAnambra State. Unpublished $\mathrm{Ph}$. D Thesis, University of Nigeria, Nsukka.

[17] Okebukola, P. A \&Ogunniyi, M. B (1984) Cooperative and competitive and individualisticlaboratory interaction patterns: Effects on achievement and acquisition of practical skillsJournal of Research in Science Teaching, 22 (9), 198 - 206.

[18] Okebukola, P. A. (1985) The relative effectiveness of cooperative and competitive interactiontechniques in strengthening students' performance in Science classes. Science Education , 69, 501-509.

[19] Oyelami M. (2000) Effective teaching techniques in teaching mechanical technology education; An overview. Nigeria Vocational Journal X; $1-5$.

[20] Udeani, U. N. (1992) Learning outcomes in integrated Science as related to teacher and student characteristics and classroom interaction pattern. Unpublished Ph. D Thesis, University of Nigeria, Nsukka.

\section{APPENDIX \\ Interaction Pattern of Economics Teachers in Cross River State Secondary Schools Dear Sir/Madam}

This questionnaire is issued for the purpose of obtaining response (data) for research on the above topic. The researcher hereby solicits your honest response. All responses (including yours) are treated anonymously, therefore the respondent stands no risk(s) in giving a honest response to all (any) items on the questionnaire.

Thanks for your cooperation.

Yours

ODU C.

\section{Questionnaire}




\section{Socioeconomic Characteristics}

Sex: $\quad$ Male

Occupation: Student

Educational Status (Student):

Educational Status (Teacher):

\section{Section A}

Data On Research Variables

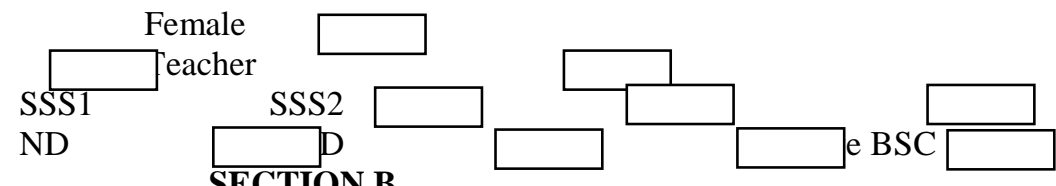

\section{SECTION B}

Below is a list of items, for each, tick as appropriate.

\begin{tabular}{|c|c|c|c|c|c|}
\hline $\mathbf{S} / \mathbf{N}$ & Teacher-Student Interaction Pattern & $\begin{array}{l}\text { Strongly } \\
\text { agree (SA) }\end{array}$ & Agree (A) & Disagree (D) & $\begin{array}{l}\text { Strongly disagree } \\
\text { (SD) }\end{array}$ \\
\hline 1 & $\begin{array}{l}\text { My Economics teacher is friendly while } \\
\text { teaching in class }\end{array}$ & & & & \\
\hline 2 & $\begin{array}{l}\text { My Economics teacher is friendly and } \\
\text { approachable outside the class }\end{array}$ & & & & \\
\hline 3 & $\begin{array}{l}\text { My Economics teacher asks questions while } \\
\text { teaching }\end{array}$ & & & & \\
\hline 4 & $\begin{array}{l}\text { My Economics teacher makes the class } \\
\text { interactive (two-way) }\end{array}$ & & & & \\
\hline \multicolumn{2}{|c|}{ Student-Student Interaction Pattern } & $\begin{array}{l}\text { Strongly } \\
\text { agree (SA) }\end{array}$ & Agree (A) & Disagree (D) & $\begin{array}{l}\text { Strongly disagree } \\
\text { (SD) }\end{array}$ \\
\hline 5 & $\begin{array}{l}\text { My Economics teacher encourages us to } \\
\text { work as study teams/groups }\end{array}$ & & & & \\
\hline 6 & $\begin{array}{l}\text { Students form study teams to study and } \\
\text { help each other academically }\end{array}$ & & & & \\
\hline 7 & I have a study team that I participate in & & & & \\
\hline 8 & $\begin{array}{l}\text { My study team helps me achieve better } \\
\text { academically }\end{array}$ & & & & \\
\hline
\end{tabular}

